\title{
Urgent Development on Contemporary Medical Fiqh in Malaysia
}

\author{
Noor Naemah Abdul Rahman ${ }^{1 *}$ \\ Mohd Anuar Ramli ${ }^{2}$ \\ Shaikh Mohd Saifudden Shaikh Mohd Salleh ${ }^{3}$ \\ Mohammad Naqib Hamdan 4
}

\author{
1*Prof Madya Datin, Pensyarah (PhD), jabatan figh and usul, Akademi Pengajian Islam, \\ Universiti Malaya \\ 2Pensyarah kanan (PhD), Jabatan Fiqh \& Usul, Akademi Pengajian Islam, Universiti Malaya \\ 3Pakar Rujuk (PhD), Program Pengajian Islam \& Sains Gunaan, Akademi Pengajian Islam, \\ Universiti Malaya \\ ${ }^{4}$ Research assistance, Jabatan Fiqh \& Usul, Akademi Pengajian Islam, Universiti Malaya
}

*Corresponding Author, Email: naemah@um.edu.my

Accepted Article: 20 August 2014

Published Article: 20 April 2015

\begin{abstract}
The contemporary scientific and technology development give impacts on the development of Islamic law. The dynamic of figh in handling issues especially on medicine become a momentum of the synergy of the two diciplines, science and the Islamic jurisprudence of medicine. Many medical issuess are yet to require legal completions that are contemporary ijtihad based on perubatan discipline. On the other hand, ijtihad not only as exclusively unilateral, moreover inclusive multilateral approach (ijtihad jama'i) is needed on handling fiqh issues. It is because expert opinions also important in describing about those issuess. Without those opinions, Islamic law scholar could not give appropriate legal decision. However, this study will explore about the importance of development of Fiqh of Medicine based on contemporary ijtihad. These studies will explain some contemporary Medicine issuees, which is proof the requirement of contemporary ijtihad. For example on the issues of reproduktif organ donation. Some ijtihad instruments which are compatible will be aplicated based on the issuess. Research findings about perubatan issuess gave fact that there were not exact explanations on al-Qur'an and al-Sunnah also did not directly examined on fiqh book in the past. This condition cause contemporary ijtihad on those studies as an important study to give law answer about perubatan issues appear. Generally speaking, the current studies require the sinergized between the dynamic of Islamic law and the advance of science and technology.
\end{abstract}

Keywords: Contemporary ijtihad, Fiqh, Fiqh of medicine, Islamic jurisprudence, Reproductive organ donation

\section{A. INTRODUCTION}

Recent development in medicine recently has initiated a new variation issuess which arehaving not been talked especially on Islamic fiqh discourse. The issues that raise such as body component's removal, from human to human or from animal to human, brain numb, cloning, stem cell treatment, in virto fertilisation test, rented womb, changing jantina, plastic or cosmetic surgery, etc. Those issuess describe clearly that medical practices have been developing rapidly. 
Equal with this development, Islamic law need to move forward as guide especially for people who involve in perubatan dan generally for Islamic society. To achieve objective opinion, need a good cooperation which build based on collective mechanism and multilateral effort. This approach significancy to get appropriate law or fatwa and fit with exact reality of science. Maklumat from expert is important for exact description to the ulama. Because, if they get wrong description, law implication which is produced will be mislead ${ }^{1}$. Prophet SAW threaten to qadi who gave fatwa or certain law which is he does not know or does not have exact description about it. Prophet SAW utterance:

$$
\begin{aligned}
& \text { القضاة الثلاثة : قاضيان في النار , وقاض في الجنة . رجال قضى بغير الحق فعلم ذلك فذاك فن النار, } \\
& \text { وقاض لا يعلم فأهلك حقوق الناس فهو فن النار, و وقاضقضى فذلك فن الجنة }
\end{aligned}
$$

Translation: There are three kinds of Qadi: Two of them will be atthe hell and one of them will be atthe heaven. Man who gives punishment without right and he does not know (the right), so he will be at the hell. And qadi who (gives law on the condition) he does not then he leaves out human right, so he will be at the hell. And qadi who gives punishment with right, so he will be at heaven².

For example, there are some ulamas who has forbide television and photography in the beginning of appearance (Al-Qaradawi, 1996) ${ }^{3}$. Their hujah because it's resembles Allah SWT creation ${ }^{4}$. The truth, they were wrong on understanding the real photographic concept because camera and television it's just a tool, no more than that (Mahmud, n.d.). If they understand this problem, there will be no fatwa like this will be release (Al-Qaradawi, 1996; Mahmud, n.d.).

Beside that, discourse between ulamas with input from expert on social science or natural science really important before determining certain fatwa. Collective ijtihad (ijtihad jama'i) is better from ijtihad unilaterally. Most of contemporary ulamas has accepted this multilateral approach and practiced on the release process of law. The result can be seen on the work of some law studies institutions. Such as, Majma' al-Figh al-Islami (Jeddah and Mekkah), Majma' al-Buhuth alIslamiyah li al-Azhar al-Sharif (Egypt), Majma' Fuqaha' al-Shari'ah (USA), and Lajnah al-Da'imah (Uni Emirat Arab). Beside that, almost every Islamic country has their own fatwa institution, as like in Arabic countries or in South East Asia.

1He is always well named as:[ الحكم على شيء فرع عن تصوه ]

2Transmitted by al-Tirmidhi di dalam Kitab al-Ahkam 'an Rasulullah saw, Bab Ma Ja'a 'an Rasulillah saw fi al-Qadi no. Hadith 1322. Lihat: Sunan al-Tirmidhi (AL-Tirmidhi, 1996), 313. al-Albani said thatthe hadith issahih (valid) 3 Look also fatwa by Dar al-Ifta' Arab Saudi, no. 260, 1953,1978, 2036, 2186, 2358. Look : Fatawa al-Lajnah alDaimah li al-Buhuth al-Ilmiyyah wa al-Ifta' (Al-Duwaysh, 1995), 454-499.

4The frequently hadith applied is :

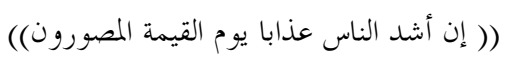

The meaning: Sesungguhnya orang yang dahsyat azabnya pada Hari Kiamat adalah orang yang membuat gambar.

The Hadith is transmitted by al-Bukhari di dalam Kitab al-Libas, Bab 'Adhab al-Musawwirin Yaum al-Qiyamah, no. hadith 5950 (Al-Bukhari, 1982); dan Muslim di dalam Kitab al-Libas, no. hadith 2109 (Muslim, 2006). 


\section{B. METHODS}

This studies will explain some contemporary Medicine issuees which is proof the requirement of contemporary ijtihad. For example on the issues of reproduktif organ donation. Some ijtihad instruments which is compatible will be aplicated based on the issuess.

\section{RESULT AND DISCUSSION}

\section{Urgension development of figh perubatan semasa in Malaysia}

There are some classic ulama on the decline era of fiqh ('asr taqlid) whose tend to said that ijtihad has been closed (Al-Zuhayli, 1986; Zahrah, n.d.) and there is no mujtahid in every time (AlZarkashi, 1992). One of the reasons that they used is ulama after the top of figh era ('asr dhahabiyyah), which is cannot raise the knowledge level as like ulama the founder of thought raise. In addition to, most of the issuess recently has been answered by them (Al-Qaradawi, 1996) or at least have similarities that can be made takyif al-fiqhi for new problem.

Actually, not all problems today have the answer on classic fiqh books. Dr. Yusuf al-Qaradawi said that today, more over after maklumat technology booming, really needed ijtihad process (AlQaradawi, 1996). He said, contemporary ijtihad that needed today can be divided by two; intiqa'i and insha'l (Al-Qaradawi, 1996)5. ljtihad intiqa'i is a process of choosing one opinion from some ulama opinions that is exist on classic books by tarjih aplication (Al-Qaradawi, 1996).ljtihad insha'i is a process of release new law for a certain problem that has not been talked by the ulama before (Al-Qaradawi, 1996). On the world of perubatan semasa, many new issuess has been appreared that has not been talked by ulama at past. It's involves issue that relate with treatment technology, surgery, stem cel technology, dan other example. This rapid development of perubatan world push to the certain urgen interest to establish figh perubatan semasa in Malaysia. If the interest does not handled in the good way, the dynamic of Islamic figh will be strict and does not relevan anymore in terms of offering law solution especially for Islamic society in Malaysia. Developing this fiqh perubatan based on collaboration multilateral inklusifly between ulama with perubatan expert, not only domination for one side. It's because, the ulama needs a deep undersanding about certain perubatan issue based on expert explanation before a law decision is decided. Failure to get input this perubatan cause a law, which is decided uneffective and unappropriate. Nevertheless, it's just based on eksclusive ulama opinion, which is iftirodi.

However, bilateral ijtihad as as mechanism of developing fiqh perubatan semasa in Malaysia need to considering these problmes for making law product effective and good (Al-Qaradawi, 1996):

1. ljtihad must be establish with maksimum effort,

2. No ijtihad on qat'i problem,

3. Zanni problem can not change as qat'i or vice versa,

4. Combining between figh and hadits,

5. Do not be bent down by surrounding pressure,

6. Taking advantage from new discovery if its benefit,

7. Take a consideration of people interest.

${ }^{5}$ Dr. Wahbah al-Zuhayli menggunakan istilah lain, yaitu al-ljtihad al-Is ta'afi. Lihat: Mawsu'ah al-Figh al-Islami wa alQadaya al-Mu'asirah (Al-Zuhayli, 2012). 
Generally, ijtihad jama'i is multilateral has been practiced since Khulafa' al-Rashidin era, more over at Khilafah Abu Bakr and 'Umar bin Khattab (Shaltut, 2007). Narrated by Maymun bin Mahran if Abu Bakr al-Siddiq faced a certain problem, he would find the answer on al-Qur'an and alSunnah. If he could not find the answer on both of them, he would ask anybody who know the answer. If there were no one who knew the answer, so he would gather scientiests and discussed before make a decision. The same way also has been done by 'Umar al-Khattab' 6 . It's compatible with Allah SWT decree:

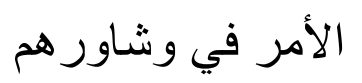

Translate: And deliberation on every problem (Ali Imran: 159).

On this verse's explanation Imam al-Qurtubi said that 'Umar bin Khattab has made a khilafah inauguration matter by deliberation process (Al-Qurtubi, 2006). Imam al-Bukhari also said that the leaders after Nabi SAW passed away would discuss with the scientiests on certain problem and would take a simpliest opinion (Al-'Asqalani, 2001; Al-Qurtubi, 2006) ${ }^{7}$. More over, Nabi SAW himself ordered shohabat discussed and deliberated if any problem appears. Shaykh Mahmud Shaltut considers this ijtihad jama'i as one of modern ijma'8, more over ijma' concept that told by classical ulama beside strict condition, as like difficult to reach it (Shaltut, 2007). So, the ulama can change one ijma' which is more suitable with problem caused by changing of era and place (Shaltut, 2007). He also adds that ijtihad jama'i will made by responsible institution must be free fro any societal and political pressure (Al-Qaradawi, 1996; Shaltut, 2007). He also supported by Dr. Yusuf al-Qardawi (1996).

However, founding process fiqh perubatan semasa in Malaysia needs clear approach, so function and role can produce law product effectively and fit with interest at that moment and place. Usually, before certain decision or interest released, experts from perubatan will explore their studies to get description clearly. With that input, law problem will be simplifiest by the ulama. This effective cooperation can develop role of figh at Islamic society in Malaysia.

Contemporary Medical Issues: the donation of Reproductive organs

Discourse on the donation of reproductive organ has been debated in Malaysia. There is no specific fatwa (scholar's decree) has been made on national level. But, for example developing of figh perubatan semasa in Malaysia, discussion of contemporary ulama about this issue can be a guideline. It is because there is fatwa or law decided by ulama without considering appropriate data caused unappropriate fatwa. Because of that, opinion and input from perubatan expert become starting point before deciding law by ulama.

Development of perubatan has created new inovasion on treatment tachnology especially involves reproduktif organ. Naturally, human reproduktif organ divided on two kinds. First variation, which is, does not consist of donatur genetic characteristic and the second one consist of donatur

\footnotetext{
6lt is hadits that related to Maymun bin Mahran:

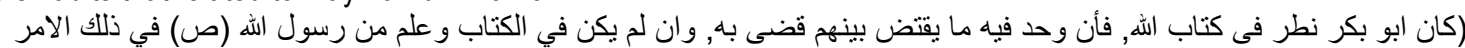

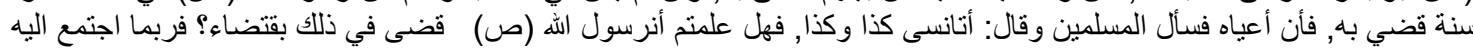

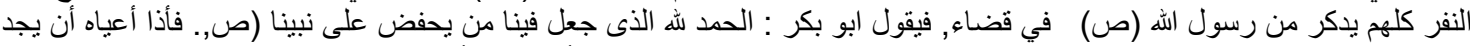

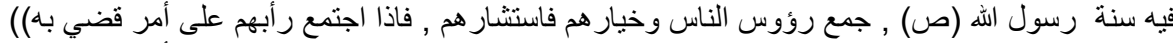

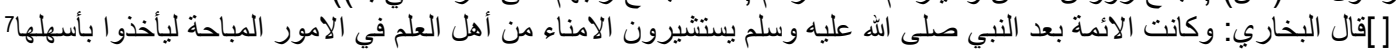

$8 \mathrm{He}$ is supported by dr. Yusuf al-Qardawy (Al-Qaradawi, 1996).
} 
genetic characteristic. First variation consist of vas deference, tuba fallopio,womb, penis and vagina. The second one is ovarium and testis.

There is three ulama's opinion about moving organ firstvariation:

i. Donation only happen if in the urgen context, except zakar and faraj,

ii. All donation is forbidden,

iii. Only moving of tuba fallopi and vas deference is acceptable, except womb, zakar and faraj.

First opinion based on hujjah that it's does not consist of genetic characteristic which is cause mixed descent. It's acceptable because urgen situation based on:

$$
\text { الضرورات المحظور ات }
$$

Translate: Every urgen situation causes urgen matter (AL-Suyuti, 1997).

However, it's a fertility's treatment which is accpetable on syara'. Exception for zakar and faraj even it's does not consist of genetic characteristic because it's supports forbidden sexual relationship (as like prostitution), and those components are forbidden to be seen if we use original law for genitals is forbidden (Marhaba, 2008). It's most of ulama's opinion such as Dr. Yusuf alQardawi9 ${ }^{9}$, Dr. Wahbah al-Zuhayli (2012), Dr. 'Ali Jumu'ah (2009), Dr. 'Ali Muhyi al-Din al-Qurrah Daghi (2008), Dr. 'Ali Muhammad Yusuf al-Muhammadi (2005), Dr. Khalid al-Jumayli (n.d.), Dr. Husayn Muhammad al-Mallah (2006), Dr. Muhammad Sayyid Tantawi, Dr. Muhammad Shibir, Dr. Muhammad Nu'aym Yasin and Dr. Faridah Zuzu, Dr. Muhammad al-Mukhtar al-Salami, Dr. Muhammad Salim bin 'Abd al-Wadud, Dr. Muhammad 'Abd al-Latif Salih al-Farfur, Dr. 'Abd alSalam al-'Abbadi and Dr. Muhammad 'Abd al-Ghaffar al-Sharif (Marhaba, 2008).

Second opinion based on some hujjah to say that law of reproduktif organ donation is forbidden. Hujah describes that it's practice consider as changing Allah SWT creation ${ }^{10}$, it's a dangerous surgery(Marhaba, 2008), will be cause an eternal barrenness (Al-Aynayn, n.d.) and it's similar with rented womb ('Uthman, n.d.). It's opinion of Dr. Hamdati Ma'al-'Aynayn (Al-Aynayn, n.d.), Dr. AlSiddiq Muhammad al-Amin al-Darir, Dr. 'Abdullah bin Bayyah, Dr. 'Ikrimah Sabri, Dr. Muhammad Ra'fat 'Uthman (n.d.), Dr. 'Abdullah bin Jabrayn, Dr. 'Abd al-Mu'ti Bayumi and Dr. Wafa' Ghanimi Muhammad Ghanimi (n.d.).

Third opinion accpetable moving of tuba fallopi and vas deference, and forbide moving of zakar, faraj and womb. It's opinion of Dr. Ra'fat 'Uthman. He gives a condition, donature tuba fallopi it's acceptable if donates one or all tuba fallopies only after mennopaus ('Uthman, n.d.). For moving organ second variation, it's can talk separately, that it is between moving testis and ovari. For testis moving, there are three ulama's opinion about it (Al-Shanqiti, n.d.):

i. Testis moving is unacceptable

ii. Testis moving is acceptable

iii. Only acceptable moving one of the testis

9Look at discusion with Maher Abdullah in the program al-Shariah wa al-Hayah, stesen al-jazeera, at April 2001, look at Maufiq al-Shari'ah min al-Tatawwurat al-'Ilmiyyah (Al-Qaradawi, 2001).

10lt is based on the revelation 
Hujah for first opinion is it's cause eternal barrenness, mixed descent because will bring donature genetic characteristic beside it's not an urgen matter. It's opinion of Dr. Muhammad al-Tayyib alNajjar, Dr. 'Abd al-Jalil Shalabi, Syeikh Ahmad Hasan Muslim, Syeikh Muhammad Ahmad Jamal (Al-Shanqiti, n.d.), Dr. Wahbah al-Zuhayli (2012), Dr. Muhammad Rashid Raghib Qabbani (2009), and Dr. Khalid al-Jumayli (n.d.). It's similar with decision of Majma' al-Fiqh al-Islami (Al-Salus, 2008).

Hujah for second opinion it's because testis only place for unites of sperm and they does not consider genetic as obstacles for testis movement. In fact, children who was born from twins couples can married each other eventhough their father have similar genetic. Nevertheles, after moving, it's already belongs to donature and does not need to look for testis background. It's the opinion of Shaykh Sayyid Sabiq (Al-Shanqiti, n.d.). Hujah on third opinion, they are comparing the necessities of one testis movement with the necessities of one loins movement. They also said, if movement of two testis ae acceptable, it will bring eternal barrenness if we compare with only movement of one testis (Al-Shanqiti, n.d.).

For ovari movement, there are two opinions. Generally, most of ulama forbide it because it will bring donature genetic characteristic by ovum cell from it's ovari ('Uthman, n.d.; Al-Jumayli, n.d.; Al-Salus, 2008; Al-Zuhayli, 2009; Ghamini, n.d.; Qabbani, 2009). If it's acceptable, there will be mixed descent between donature and receiver. They also said, it can be washed or cleaned by perubatan expert and cause no genetic characteristic movement after ovari movement. It's the opinion of Dr. 'Umar Sulayman al-Ashqar (n.d.)'

Based on that opinion, there are clear differentiations on ulama area shows collaboration interests as multilateral between ulama with perubatan expert for fiqh perubatan development semasa. The failure of good cooperation cause relevancy crisis Islamic law as solution that impressed for Islamic society, and outhority and integrity of fatwa and law are debatable. It's because of did not consider fact of perubatan semasa.

\section{CONCLUSION}

Development of fiqh perubatan semasa in Malaysia is an urgen matter. Every day appears new complicated issues. As comprehensif Syariah, Islam offers practical solution dan guideline for those advances.

Involvement of expert of perubatan on decision semasa law is really needed. Ulama missunderstanding on understands certain issues will produce unappropriate law interest. However, cooperation multilaterally between the ulama dan expert really important on development of perubatan semasa in Malaysia.

\footnotetext{
11 but there are some people clam that he was.... after beind expalined by some docter that ovum in the overi is can be removed as it was there from the born. Look at al-dwabit al-shar'iyyah (Ghamini, n.d.).
} 


\section{References}

'Uthman, M. R. (n.d.). Naql wa Zar' al-A'da'.

Al-'Asqalani, A. bin 'Ali bin H. (2001). Fath al-Bari bi Sharh Sahih al-Bukhari (1st ed.). Riyad: 'abd al-Qadir Shaybah al-Hamd.

Al-Ashqar, M. S. (n.d.). Naql wa Zira'ah al-A'da' al-Tanasuliyyah.

Al-Aynayn, H. M. (n.d.). Zira'ah al-Ghadad al-Tanasuliyyah au Zira'ah Rahm Imra'ah fi Rahm Imra'ah Ukhra.

Al-Bukhari, A. 'Abdillah M. bin I. (1982). Al-Jami' al-Sahih al-Musnad min Hadith Rasulillah saw wa Sunanihi wa Ayyamihi (Sahih al-Bukhari). (M. al-D. Al-Khatib, Ed.) (1st ed.). Kaherah: alMatba'ah al-Salafiyyah.

Al-Duwaysh, A. bin 'Abd al-R. (Ed.). (1995). Fatawa al-Lajnah al-Da'imah li al-Buhuth al-"Ilmiyyah wa al-Ifta" (1st ed.). Riyad: Dar al-Mu'ayyid.

Al-Jumayli, K. R. (n.d.). Naql A'da al-Janin al-Naqis al-Khilqahfi al-Shari'ah al-Islamiyyah.

Al-mallah, H. M. (2006). al-Fatawa: Nash'atuha wa Tatawwuruha, Usuluha wa Tatbiqatuha. Beirut: al-Maktabah al-'Asriyyah.

Al-Muhammadi, 'Ali Muhammad Yusuf. (2005). Buhuth Fiqhiyyah fi Masa'il Tibbiyyah Mu'asirah (1st ed.). Beirut: Dar al-Basha'ir al-Islamiyyah.

Al-Qaradawi, Y. (1996). al-ljtihad fi al-Shari'ah al-Islamiyyah ma'a Nazarat Tahliliyyah fi al-ljtihad al-Mu'asir (1st ed.). Kuwait: Dar al-Qalam.

Al-Qaradawi, Y. (2001). Maufiq al-Shari'ah min al-Tatawwurat al-'Ilmiyyah. Retrieved from http;//www.aljazeera.net/home/print/0353e88a-286d-4266-82c6-6094179ea26d/a3dflaob71b3-a77-ac12-daeb7a1f27e8

Al-Qurtubi, A. 'Abdillah M. bin A. bin A. B. (2006). Al-Jami'li Ahkam al-Qur'an. ('Abdullah bin 'Abd al-Muhsin Al-Turki, Ed.) (1st ed.). Beirut: Muassasah al-Risalah.

Al-Salus, A. A. (2008). Mausu'ah al-Qadaya al-Fiqhiyyah al-Mu'asirah wa al-lqtisad al-Islami (11th ed.). Beirut, Qatar, Kaherah: Muassasah al-Rayyan, Dar al-Thaqafah, Maktabah al-Tirmidhi and Maktabah Dar al-Qur'an.

Al-Shanqiti, M. bin M. al-M. (n.d.). Ahkam al-Jirahah al-Tibbiyyah wa al-Athar al-Mutarattibah 'Alayha. Jeddah: Maktabah al-Sahabah.

AL-Suyuti, J. al-D. 'Abd al-R. (1997). al-Ashbah wa al-Naza'ir fi Qawa'id wa Furu' Figh alShafi'iyyah. Riyad: Maktabah Nizar Mustafa al-Baz.

AL-Tirmidhi, M. bin 'Isa bin S. (1996). Sunan al-Tirmidhi. (M. bin N. al-D. Al-Albani \& A. 'Ubaydah M. bin H. A. Shaykh, Eds.) (1st ed.). Riyad: Maktabah al-Ma'arif. 
Al-Zarkashi, B. al-D. M. bin B. bin 'Abdullah al-S. (1992). al-Bahr al-Muhit fi Usul al-Fiqh. ('Abd alSattar Abu Ghuddah \& 'Abd al-Qadir 'Abdullah Al-'Ani, Eds.) (2nd ed.). Kaherah: Dar alSafwah.

Al-Zuhayli, W. (1986). Usul al-Fiqh al-Islami (1st ed.). Damsyiq: Dar al-Fikr.

Al-Zuhayli, W. (2009). Zira'ah wa Naql al-A'da'.

Al-Zuhayli, W. (2012). Mawsu'ah al-Fiqh al-Islami wa al-Qadaya al-Mu'asirah (3rd ed.). Damsyiq: Dar al-Fikr.

Daghi, et al. (2008). Figh al-Qadaya al-Tibbiyyah al-Mu'asirah (3rd ed.). Beirut: Dar al-Basha'ir alIslamiyyah.

Ghamini, W. (n.d.). al-dwabit al-shar'iyyah.

Jumu'ah, A. (2009). Fatawa al-Bayt al-Muslim (1st ed.). Kaherah: Dar al-Imam al-Shatibi.

Mahmud, 'Abd al Hamid. (n.d.). Fatwa al-Imam 'Abd al-Halim Mahmud. Kaherah: Dar al-Ma'arif.

Marhaba, I. (2008). al-Bunuk al-Tibbiyyah al-Bashariyyah wa Ahkamuha al-Fiqhiyyah (1st ed.). Riyad: Dar Ibn al-Jauzi.

Muslim, A. al-H. M. bin al-H. al-Q. al-N. (2006). Al-Musnad al-Sahih al-Mukhtasar min al-Sunan bi Naql al-'Adl 'an al-'Adl ila Rasulillah saw (Sahih Muslim). (A. Q. N. M. Al-Fariyabi, Ed.) (1st ed.). Riyad: Dar Tayyibah.

Qabbani, M. R. R. (2009). Naql al-A'da' wa Zar'uha.

Shaltut, M. (2007). Al-Islam: Aqidah wa Shari'ah (29th ed.). Kaherah: Dar al-Shuruq.

Zahrah, M. A. (n.d.). Muhadarat fi Tarikh al-Madhahib al-Fiqhiyyah. Kaherah: Matba'ah al-Madani. 